\title{
Language Policy Debate in Ghana: A Means of Elite Closure
}

\author{
Albert Agbesi Wornyo ${ }^{a}$
}

\begin{abstract}
The language policy in Ghana's educational system has become an issue of debate in recent years. A change in the language policy from the local languages as the medium of instruction to English for the first three years of primary school in the year 2002 was reversed in 2004. It is obvious that the language policy adopted does not reflect in improvement in school achievement. The debate must go beyond the use of English or the local languages for the first three years of primary education to address the real issues that hinder school achievement. This paper examines the factors that hinder school achievement in Ghana and other developing countries. The paper argues that the problem of poor academic performance in Ghana is not due to the language policy adopted. The paper points out that the language policy is just a veil that the politicians use to perpetuate the use of English as the language of rule in the higher domains in order to preserve the privileges with which this language is associated. The paper concludes that politicians in Ghana use the language policy in education as a means to perpetuate elite closure.
\end{abstract}

Keywords

Elite closure, language policy, school achievement

Language in education, according to Anyidoho (2012), has been debated again and again during both the preand post-independence periods, not only in Ghana but in many African countries as well. She added that the topic is "old and yet so relevant... that no amount of time and energy spent debating it can be deemed superfluous” (Anyidoho 2012: 1503). Language policy of education in Ghana is therefore a familiar topic. The focus of much of the debate has been whether to use the child's first language (L1) as medium of instruction in education or to use English or both. This paper examines the current language policy debate which started in 2002 as a result of a change in the policy from the use of a Ghanaian language at the lower primary school level as medium of instruction to English only from class one. The paper considers the change and the reasons associated with it as one of the means by which the politicians (ruling elites) pay lip service to the language policy of education and use it as one of the means to perpetuate elite closure. For this point to be well-made, a brief background of how modern politics started in Ghana and other African countries is provided.

Most African countries were created out of the partitioning of the African continent by the colonial powers that invaded the continent in the eighteenth century. What existed in the African continent before the coming of the Europeans were ethnic-based states

aUniversity of Education, Winneba, Ghana

\section{Correspondent Author:}

Albert Agbesi Wornyo, Department of Communication and Media Studies, University of Education, Winneba, Ghana

E-mail: awornyo@yahoo.com; aawornyo@uew.edu.gh 
or kingdoms that were fighting one another. The partitioning of the continent by the colonial powers led to the situation where a number of these ethnic-based states were brought together under one colonial authority and consequently became nation-states.

The amalgamation of a number of ethnic-based states under one colonial administration led to the bringing together of people who speak different languages as one country. This has created a multilingual situation in most African countries. Examples of African countries that were created through the amalgamation of a number of ethnic-based states are Ghana, Nigeria, Senegal, South Africa, Kenya, and Uganda. Multilingualism comes with its problem of language planning and policy of allocating functions to the languages that are used in the society.

The African countries created as a result of different ethnic groups brought together under one colonial administration are faced with the issue of integration especially after independence. These countries are faced with the task of ensuring that the various ethnic groups continue to stay together as a country after the departure of the colonial masters. There is also the concern for these countries made up of different ethnic groups to forge a bond of belonging together as nationals of a state. Because the different ethnic groups that were brought together under one colonial administration speak different languages, the African countries after independence adopted the language of their colonial masters as their official language. The colonial languages were adopted as the official language for the purpose of national integration as well as to serve as the medium of instruction in the educational system of the post colonial countries. The European languages were adopted as official languages because they are neutral in that they do not belong to any ethnolinguistic group within the country. For this reason, most African countries adopted English or French as their official languages. In the case of Ghana, English became the official language of the country.

The colonial languages selected as the official languages have become the languages used to perform a number of functions in the new African countries. First, the official languages serve as the spoken language of the government officials in their official duties at the national level. Second, they serve as the language of written communication between and within government agencies at the national level. They also serve as the languages in which government records are kept at the national level. In addition, they are the languages in which laws and regulations governing the nation as a whole are originally written. The official languages have become the languages in which forms such as tax forms and various applications related to the national government are published.

The African countries created as a result of colonialism have now become nation-states with one official language through which country men and women gain access to economic resources and political power. The nation-state throughout Africa especially after independence became the most powerful form of political organization. Once an African country gained independence, all the ethnic groups and villages that fall within the territory of that nation-state must contribute to the economic and political development of that country. In other words, the political power at the national level controls all the ethnic groups and villages in that country. The nation-states therefore have the fundamental function of allocating among social groups access to economic resources and political power.

As a result of the responsibility of the nation-state to allocate economic resources to various social groups in the country, many human activities have been penetrated by the state including the language that is used in education. Every decision is taken at the national level. And whatever decision is taken must be carried out in all villages in the country. Competence 
in the official language becomes the means by which individuals gain access to issues of governance in the country. Competence in the official language has become crucial to the quality of life of the individual. In Ghana and every African country, it is individuals who get access to quality education and are able to gain access to tertiary education who stand the chance of getting appointment as government officials. And it is these individuals who become the educated elites of the country.

As a result of the colonial school system that came with colonialism, a class of African elites emerged in Africa composed of Africans who have acquired Western education. This class of Africans, referred to as African elites have become the rulers of the nation-states created as a result of colonialism. Eke (1975) referred to this class of Africans as the African bourgeois and pointed out that colonialism led to the emergence of a class of Africans who have acquired Western education (the educated elites) and the rest of Africans as the natives. It is this class of Africans who have acquired Western education who have become the rulers of the natives (the masses) after independence. It is this class of Africans who live modern European lifestyles. They are more exposed to the outside world and have become modern Africans. For this reason, the concern of families and households that fall within the masses in African communities has become a focus on how to let their children go to school so that when they complete school they would get jobs as top government officials to become part of the educated elites.

It is important to note that at the time of independence the colonial masters handed the mantle of governance to the educated elites. It is also important to note that the educated elites actually demanded that the governance of their countries be handed over to them. They objected to the involvement of the chiefs in colonial administration because they felt the chiefs were not educated. Yakohene (2009) stated that the integration of British territories within West Africa was spearheaded by Joseph Ephraim Casely-Hayford, an educated elite from Ghana (Gold Coast) who convened the inaugural meeting of the National Congress of British West African States (NCBWA) in Accra in 1920. She stated that some of the outcomes of their first and subsequent meetings, included the demand for the election of African representatives to the Municipal and Legislative Councils and the opening up of the Civil Service to Africans. Quarcoopome (1991) also pointed out that after much protest by the NCBWA in 1924, the colonial government in the Gold Coast proposed municipal councils to be headed by mayors, not from the ranks of the traditional rulers anymore but from the ranks of the Western educated elites only.

Initially the colonial masters were using the chiefs as representatives of the people in the colonial parliament. The Africans who received formal education were those who became the nationalists and started asking the colonial government for reforms. The educated elites through their nationalist movements objected to the colonial government's use of chiefs in the colonial parliament. They argued that the educated elites should be nominated to the colonial parliament. The educated elites in Africa regarded themselves as people who should take decisions in parliament and be appointed to positions as government officials even under colonial administration.

Therefore, when political power was handed over to the educated elites after independence, they began to take decisions that would let them maintain their positions of authority over the masses and subsequently pass their political positions onto their children and relatives. The educated elites are aware that an individual's access to economic and political power is enhanced through the individual's command of the official language of the country. The official languages of most African countries are acquired through the educational system because the official languages are not indigenous languages. It could be 
argued that all the policies that are taken about the educational system in African countries are taken with the interest of the educated elites to remain in authority and rule over the masses.

This paper argues that the issue of policies in the educational system of most African countries is a decision that is taken with the interest of the educated elites to maintain their position in authority in order to rule over the masses. The paper argues that the language policy debate in Ghana's educational system and most African countries is just one of the means that the politicians use to prevent the masses from getting access to quality education. The paper examines the issues surrounding the current debate over the language policy of Ghana and points out that the politicians who take the decision are not committed to their own educational system. Whatever policies they take about the educational system are just taken as a matter of what is convenient to let them continue to maintain their positions as the ruling elites and for the masses to feel that they are doing something to fix the problems in the educational system.

\section{A BRIEF OVERVIEW OF LANGUAGE POLICY OF EDUCATION IN GHANA}

Alidou (2004) pointed out that education in rural villages before the nation-state and before colonialism was carried out in local languages without concern for imposed external varieties. As the case is, it is obvious and common knowledge that it is the introduction of the nation-state and colonial educational system that the debate about the medium of instruction arises. In Ghana, formal education started with what is known as the castle schools. According to Ansah (2014), these were schools that were established by the European settlers at their forts [The Christianborg Castle Accra (Danish), Elmina Castle (Portuguese then Dutch), and the Cape Coast Castle (British)] to provide education to children and relatives of wealthy
African merchants, children and relatives of some important chiefs but largely Molato children of European castle staff by African women. These schools were not meant for the formal education of indigenous Ghanaian children.

Formal education in Africa therefore started as a means of training Molato children and the children of wealthy African merchants and relatives of some important chiefs. It is some of these children of wealthy African merchants and important chiefs who became the educated elites and subsequently became rulers of the masses in the nation-states that were created later. Let us note that the chiefs were the rulers of the people in Africa before the arrival of the Europeans. Formal education therefore started by training their children who later became rulers in the nation-states that were created as a result of colonial administration.

The medium of instruction in the castle schools was the European languages. The arrival of the missionaries caused the medium of instruction to change from the European languages to the local languages. Agbedor (1994) stated that most of the mission schools adopted a mother tongue based education policy, using the native languages of the localities in which they operated as the medium of instruction in formal education. It should be noted however that not all the missions used the native languages of the localities where they operated. Some of them used the European languages as medium of instruction. Andoh-Kumi (1994) observed that the language policies within the period of the mission schools were varied. The period of the mission schools was between 1529-1925. This period is referred to as the pre-colonial era.

The colonial period started in 1925. The British colonial government took over the administration of education in the then Gold Coast in 1925. According to Bamgbose (2000), the use of the native language as medium of instruction in the mission schools was widespread that the British administration did not 
change the policy. The use of the native languages as the medium of instruction for the first three years lasted until independence. It should however be noted that according to Ansah (2014), the encouragement of the vernacular in education was interpreted by the people of Ghana as a somewhat "deliberate attempt by the British government to provide inferior education to the Africans, perhaps because of the negative connotations, (e.g. non-standard, non-literary, and not cultured) that were typically associated with the term 'vernaccular'”.

The use of the native languages as medium of instruction at the lower primary level was reversed after independence. The first indigenous government that took over in 1957 abolished the use of Ghanaian languages as medium of instruction at the lower primary level and opted for English only as medium of instruction from primary one. After independence, the language policy of education in Ghana has been unstable. Owu-Ewie (2006: 77) put it this way: "Since then, the use of the Ghanaian languages as the medium of instruction at the lower primary level has had a checkered history”. Ansah (2014) described the language policy after independence as the most fluctuating. Owu-Ewie (2006: 77) gave the breakdown of how the policy had fluctuated between 1957 and 2002 as follows:

From 1957 to 1966, a Ghanaian language was not used at all; from 1967 to 1969, it was used only for the first year; and between 1970 and 1974, a Ghanaian language was used for the first three years and where possible beyond (to the sixth year); from 1974 to 2002, a Ghanaian language was used for the first three years.

Let us take note that the use of a Ghanaian language for the first three years became a stable policy for 28 years. At the least, this became the policy that Ghanaians had become used to until the sudden change in 2002 which has rekindled the language policy of education debate in Ghana.

\section{THE CURRENT LANGUAGE POLICY DEBATE IN GHANA}

In 2002, the language policy that had been used for 28 years was changed by the government to an English-only policy as medium of instruction but made room for a Ghanaian language to be studied as a subject up to the senior high school level. According to Akyeampong (2004), it came as a very big surprise when the Ghanaian government suddenly announced a change to English as the medium of instruction from primary 1 , without initiating any review process. He indicated that the announcement was greeted with anger, disbelief, and as a betrayal of commitment to sound educational policy for promoting quality basic education by some of Ghana's development partners.

However, according to the minister of education at the time, the government's decision was informed by the realization that the previous policy was abused by some schools, especially, in the rural areas of the country. He alleged that the abuse of the policy had resulted in the situation where some teachers never used English in the classroom throughout primary school education. This, according to the minister, had resulted in the situation where students are unable to speak and write "good" English sentences even by the time they complete the senior high school.

A common problem with the educational system of most African countries is the issue of falling standards of English in the educational institutions. In Ghana, the fear of falling standards of English has been an issue in several reports as well as articles that appear in some newspapers. The Chief Examiners' Reports of the West African Examination Council for example have highlighted this problem of falling standards of English at the junior high school and the senior high school levels. Examples of some of these reports are the General Resume of Chief Examiners Report on the November/December 2011 and May/June 2012 West African Senior School Certificate Examination conducted in Ghana. The 
minister therefore blames the abuse of the language policy, the excessive use of Ghanaian languages in some schools as the cause of falling standards of English in the schools.

Is underachievement in Ghanaian schools due to the abuse of the language policy? Even if it is due to the abuse of the language policy, it is obvious that even the minister recognizes that the problem is not the language policy but rather the poor implementation of the policy. If it is due to the implementation of the policy why not address the problem with the implementation of the policy? Should the policy be changed because it has not been well-implemented?

The minister's claim that the abuse of the language policy is the cause of students' inability to speak and write good English even by the time they complete senior high school is difficult to accept. The language policy of using a Ghanaian language as medium of instruction for the first three years at the primary school is not in any way related to the medium of instruction at the senior high school level. The medium of instruction at the senior high school in Ghana is English. One is at a loss how the language policy of using a Ghanaian language as the medium of instruction for the first three years in primary school, applicable to only the lower primary school level could be said to be responsible for students' inability to speak and write good English even by the time they complete senior high school.

In a reaction to the minister's claim that the abuse of the language policy has led to the situation where students are not able to speak and write good English even after they complete senior high school, Owu-Ewie (2006) pointed out that "The poor academic performance in Ghanaian schools, especially in English proficiency, is not caused by the use of Ghanaian language as medium of instruction at the lower primary level, as erroneously perceived by many”. This observation is very true. We cannot attribute the problem of underachievement in
Ghanaian schools to the language policy.

Contrary to the minister's claim, evidence has shown that the use of the $\mathrm{L} 1$ as medium of instruction in the education of children during their formative years facilitates proficiency in English and general academic achievement. For example, Ferguson (2013: 26) cited a study by Williams (1996) which "shows that Year 5 primary pupils in Malawi, where Chichewa is the medium up to Year 4, have no worse reading abilities in English and better Chichewa/Nyanja abilities than Year 5 pupils in Zambia, where the official medium from Year 1 is English”. In addition, experiments conducted with local language medium of instruction in Nigeria (Fafunwa, Macauley, and Sokoya 1989) also showed that pupils who were instructed in their native Yoruba gained proficiency in English better.

It is also argued sometimes that the poor quality of education in many developing countries is due to the use of unfamiliar language as medium of instruction but this argument has not been proven. Some studies conducted have shown that students' performance is not dependent on the language used as medium of instruction. Real-Dickins, Khamis, and Olivero (2013: 113) stated that "In Sub-Saharan Africa, a significant number of children demonstrate their school achievement through formal examinations administered through a second language (L2) with English predominating as the medium of instruction and examining in much of the region". This statement is applicable to Ghana. Much of the complaints about falling standards of English and underachievement in schools come from the performance of students at the junior and senior high school levels.

To find out the role of an unfamiliar language as a mediating tool for subject learning, Real-Dickins et al. (2013) conducted a study in Tanzania. In their study, secondary school students were offered the opportunity to answer examination questions in Kiswahili or English or both. In presenting the findings of their study, they indicated that "There is 
no simple conclusion to be drawn about which language best enables students to demonstrate their school learning and, hence, no easy policy solutions” (Real-Dickins et al. 2013: 120). In the conclusion of their study, they stated that changing the language medium of examinations will not resolve the problem of poor quality education as both languages—Kiswahili and English—-have been shown to introduce some construct-irrelevant variance in the formal examination of student achievement in their various school subjects. This is clearly an indication that the problem of falling standards in educational achievement recorded in developing countries in Africa is not due to the language used as medium of instruction in the educational system of the countries involved.

In fact, in the view of this paper, the language policy is just being used as a veil to cover the real factors responsible for underachievement in the educational system. The politicians are aware of factors such as teacher shortages, lack of qualified teachers, teacher absenteeism, lack of supervision, inadequate resources and so forth as responsible for underachievement in the schools. In Ghana, the pattern that has emerged and continues to exist is that in general terms, at the basic school level, pupils who attend private schools perform better than pupils who go through the government schools (public schools). Why is this the case? It is common knowledge that in the private schools, the performance of the pupils is what determines whether parents will send their wards to the school or not. Because of this, the proprietors do their best to ensure strict supervision and make sure that contact hours are utilized by the teachers. If they fail to do that and the pupils do not do well academically, parents will not bring their wards to the schools. What happens in the public schools? Is the same kind of strict supervision carried out?

Several studies and reports have shown that the poor academic performance in Ghanaian schools in general including poor English proficiency as the case is in many developing countries is due to problems of teacher supply and material shortages. There have been reports of shortage of desks for pupils to sit at, shortage of classroom useable in rainy weather (popularly known among Ghanaian politicians as schools under trees), and a low textbook-pupil ratio. The situation of classrooms that are not useable under rainy weather in Ghana is so severe that a World Bank report in 2004 indicated that only 66\% of classrooms are useable during rain (Word Bank 2004).

Apart from material shortage which includes shortage of teachers, there is also teacher absenteeism. Again, according to World Bank (2004), teacher absenteeism has been on the rise in Ghana. There is also weak teacher morale and low commitment to work on the part of teachers in Ghana. These are some of the causes of poor quality education in Ghana and other African countries. These are the problems that the politicians and policy makers in developing countries ought to address and stop changing the language of education policy.

The other reasons given by the minister for the change in the language policy are all related to lack of teachers to teach the Ghanaian languages as well as lack of materials in the Ghanaian languages. With regards to the issues raised about the Ghanaian languages, the point made by Akyeampong (2004) should be considered. He stated that we need to draw attention to the fact that the earlier policy did not go far enough to promote interest in learning Ghanaian languages. He added that the government's action is a mixed blessing. What it has done is to create the forum to revisit the arguments and face up to the difficult challenge of introducing a viable language policy for many post colonial governments. As noted by Akyeampong, the government's announcement of the introduction of an English only language policy in education led to criticisms and fierce debate in the country. The linguists in the various universities in the country did not take the change in the language policy kindly at all. 
In 2004, the same government that changed the language policy to English only medium reversed the policy to the use of Ghanaian languages as medium of instruction for the first three years. Why should the same government reverse the policy without any explanation? It is obvious that the language policy is not the cause of underachievement in the educational system. Does it show that the politicians are really convinced and committed to the issue of language policy of education in Ghana?

\section{LANGUAGE POLICY IN GHANA AS A MEANS OF ELITE CLOSURE}

Kamwangamalu (2013) observed that most African countries have opted for former colonial languages such as English, French, and Portuguese in domains such as education, parliament, government and administration, and the economy so that this becomes the language of rule. The colonial language then becomes the language through which the ruling elites structure social inequalities. This is what this paper believes is happening with the case of the language policy of education in Ghana where the ruling elites (the politicians) play blame game with the language policy to make it look to the masses that the language policy is the cause of underachievement in the schools. By doing this, the factors that lead to underachievement remain unresolved and they covertly succeed in keeping the masses, especially the rural poor from getting access to quality education. As a result, the children of the rural poor do not become competent in the language of rule to enable them get access to tertiary education. And without tertiary education, they cannot get appointment to positions as government officials.

Scotton (1990) cited in Kamwangamalu (2013), defined elite closure as the vested interest of the elite in perpetuating the use of the language of rule in the case of Ghana, English in the higher domains in order to preserve the privileges with which this language is associated. By so doing, the elites isolate themselves with their privileged language, English, with which they discuss issues of governance. What happens in this case is that language use by the ruling elites becomes compartmentalized: They use the language of rule for intra-elite communication, and an indigenous language for communication with the masses. This paper believes that this phenomenon is applicable to the ruling elites in Ghana. In parliament and the transaction of government business, English, the official language is used but when the politicians are soliciting the vote of the masses during presidential and parliamentary elections, they use the indigenous languages to interact with the masses in the towns and villages that they go to conduct their campaigns.

The language in education policy as a means of elite closure is so applicable to the ruling elites of Ghana to the extent that the ruling elites tend to covertly resist the language in education policies that they themselves have designed for the public schools. The politicians and top government officials as well as most educated people in Ghana prefer to send their own children to private schools where there is strict supervision. Hillman and Jenker (2004) have hinted that public schools may be a low priority if the country's economic and political elites send their children to private school. This is the situation in Ghana. The ruling elites care very little about the quality of education in the public schools. The ruling elites do not have confidence in the kind of educational policies that they have formulated to regulate the public schools. Because of this, they rather send their own children to private schools. This practice by the ruling elites is not peculiar to Ghana. Kamwangamalu (2013) argued the case of elite closure in the monolingual Kingdoms of Lesotho and Swaziland and pointed out that the practice is widespread in African countries. Some of the ruling elites even send their children to Europe and America to be educated. Ferguson (2013: 29) also referred to 
the vested interest of the elites in policy on medium of instruction and stated that:

The vested interest argument... proposes that the retention of English-medium education helps elites maintain their privileged status by excluding the mass of the population, who have less easy access to the language and hence the opportunities it offers. They are thus better able to reproduce their privilege in the succeeding generation.

Moreover, the ruling elites and top government officials prefer to send their wards to private schools because they know that supervision in the public schools is porous. They are aware that if they send their wards to the public schools, they are not likely to attain competence in the English language and their overall educational achievement will be poor. So, the ruling elites in Ghana prefer not to get the problems of the educational system fixed. Rather, they pretend to put the blame on the language policy and keep changing it from time to time to let the masses feel that they are trying to solve the problems in the educational system. It is the poor who suffer because they cannot afford to send their children to the private schools. The vicious cycle of poverty then continues because failure to achieve success at school has the consequence of the individuals not being able to achieve their potential. Such individuals remain on the periphery of society. They are not able to get jobs that will make them earn a descent living.

It has been pointed out that poor educational attainment in most low-income countries is partly due to the vested interest of the educated elites. Hillman and Jenker (2004) writing for the International Monetary Fund (IMF), stated that the disparity in educational attainment between children from poor families and children from affluent families is wide in low-income countries like Bangladesh, Ghana, and Indonesia. They also point out that the lack of political will to provide quality education in poor countries may be due to the fear of the ruling elites that an educated population will be better equipped to challenge them. This observation is application to the ruling elites in Ghana. They lack the political will to provide quality education. One can infer that it is because they prefer to keep the masses poor so that they will continue to maintain their positions as the ruling class over the masses.

\section{CONCLUSIONS}

The problem of underachievement in Ghanaian schools continues to persist despite the frequent change in the language policy of education. The use of Ghanaian languages for the first three years at the lower level of primary school cannot be said to be responsible for underachievement or falling standard of English proficiency in the schools. It is therefore suggested that the blame game that the ruling elites are playing with the language policy is just a means of perpetuating elite closure: to preserve the language of rule, the English language with the privileges that it has to themselves and their children and relatives. This is because the ruling elites and those who are wealthy in Ghana do not send their children to the public schools. It is the poor people whose children go to the public schools.

\section{References}

Agbedor, P. K. 1994. "Language Planning for National Development: The Case of Ghana.” Unpublished PhD thesis. University of Victoria, British Columbia, Canada.

Akyeampong, K. 2004. "The Language Policy Debate in Ghana: Where Has It Gone Wrong?” Norrag News. Retrieved (http://www.norrag.org/cn/publications/norrag-news/online -version/language-politics-and-the-politics-of-language-in-e ducation/detail/the-language-policy-debate-in-ghana-where -has-it-gone-wrong.html).

Alidou, H. 2004. "Medium of Instruction in Post-Colonial Africa.” Pp. 195-214 in Medium of Instruction Policies: Which Agenda? Whose Agenda, edited by J. W. Tollefson and A. B. M. Tsui. Mahwah, NJ: Lawrence Erlbaum.

Andoh-Kumi, K. 1994. "Topics in Ghanaian Language Education.” Unpublished.

Ansah, G. N. 2014. "Re-examining the Fluctuations in 
Language-in-Education Policies in Post-Independence Ghana.” Multilingual Education 4(12). Retrieved (http://www.multilingual-education.com/content/4/1/12).

Anyidoho, A. 2012. "First Language in the Education of Children in Multilingual Ghana Revisited.” Pp. 1503-1518 in Reclaiming the Human Sciences and Humanities Through African Perspective (Vol. 2), edited by H. Lauer and K. Anyidoho. Accra: Sub Saharan Press.

Bamgbose, A. 2000. Language and Exclusion. Piscataway, NJ: Transaction Publishers.

Eke, P. 1975. "Colonialism and the Two Publics in Africa: A Theoretical Statement." Comparative Studies in Society and History 17(1):91-112.

Fafunwa, B. Y., J. Macauley, and J. Sokoya, eds. 1989. Education in the Mother Tongue: The Primary Education Research Project (1970-78). Ibadan: University Press.

Ferguson, G. 2013. "English, Development and Education: Charting the Tensions." Pp. 21-44 in English and Development: Policy, Pedagogy and Globalization, edited by E. J. Erling and P. Seargeant. Ontario: Multilingual Matters.

General Resume of Chief Examiners Reports on the May June 2012 West African Senior School Certificate Examination Conducted in Ghana. 2012. Retrieved (http://www.ghanawaec.org/Exam/ExaminerWAECMAYJ UNE.aspx).

General Resume of Chief Examiners Reports on the November December 2011 West African Senior School Certificate Examination Conducted in Ghana. 2011. Retrieved (http://www.ghanawaec.org/ExamStatistics/ExaminerWAE CNOVEMBERDECEMBER.aspx).

Hillman, A. L. and E. Jenker. 2004. Educating Children in Poor Countries. International Monetary Fund. Retrieved (http://www.imf.org/external/pubs/ft/issues/issues33/).

Kamwangamalu, N. M. 2013. "Language-in-Education Policy and Planning in Africa's Monolingual Kingdoms of Lesotho and Swaziland.” Pp. 156-171 in Language Policies in Education, edited by J. W. Tollefson. New York, NY: Routledge.
Owu-Ewie, C. 2006. “The Language Policy of Education in Ghana: A Critical Look at the English-Only Language Policy of Education.” Pp. 76-85 in Selected Proceedings of the 35th Annual Conference on African Linguistics. Somerville, MA: Cascadilla Proceedings Project.

Quarcoopome, S. S. 1991. "The Politics and Nationalism of A. W. Kojo Thompsom: 1924-1944.” Research Review 7(1\&2):11-21.

Real-Dickins, P., Z. K. Khamis, and F. Olivero. 2013. "The Relationship Between English-Medium Instruction and Examining and Social and Economic Development: A Sub-Saharan African Case Study.” Pp. 111-140 in English and Development: Policy, Pedagogy and Globalization, edited by E. J. Erling and P. Seargeant. Ontario: Multilingual Matters.

Scotton, C. M. 1990. "Elite Closure as Boundary Maintenance.” Pp. 25-52 in Language Policy and Political Development, edited by B. Weinstein. Norwood, NJ: Ablex.

Williams, E. 1996. "Reading in Two Languages at Year Five in African Primary Schools.” Applied Linguistics 17(2):182-209.

World Bank. 2004. Books, Buildings and Learning Outcomes: An Impact Evaluation of World Bank Support to Basic Education in Ghana. Washington, D.C.: World Bank.

Yakohene, A. B. 2009. "Overview of Ghana and Regional Integration, Past Present and Future.” Pp. 1-22 in Ghana in Search of Regional Integration Agenda, edited by Friedrich-Ebert-Stiftung. Accra: Friedrich-Ebert-Stiftung.

\section{Bio}

Albert Agbesi Wornyo, B.A (Hons) Psychology and Linguistics, M.Phil Teaching English as a Second Language (University of Ghana, Legon), lecturer, Department of Communication and Media Studies, University of Education, Winneba, Ghana; research fields: rhetoric, critical discourse analysis, teaching English as a second language, and media discourse. 